\title{
Taxing the Digital Economy
}

Intertax dedicates this issue - another special issue - to taxing the digital economy, with seven articles contributing to the scientific and policy debate at the highest level. I am very proud to publish the outcome of again excellent and multidisciplinary research on the topic, by economists and lawyers, with international and European Union insights.

Seven articles discuss the topic from varying angles: tax competition for investment in digital business models; the relevance of user contribution and sustained user relationships (SURE) to value creation; the qualification of the digital services tax; the compatibility of the digital services tax in the EU Proposal for a Directive with the fundamental freedoms of goods and services; and a regulatory framework for the taxation of virtual currency transactions.

Our guest editorial ('Qualification of the Digital Services Tax under Tax Treaties') has been written by Daniela Hohenwarter, Georg Kofler, Gunter Mayr and Julia Sinnig. They are the authors who supported the Austrian Presidency of the Council of the European Union, with an earlier version of this article. Hohenwarter, Kofler, Mayr and Sinnig discuss the 'Qualification of the Digital Services Tax under Tax Treaties' in the European Commission Proposal, by putting forward several arguments in support of the conclusion that the digital services tax in the afore-mentioned Proposal is not an income tax (as the tax base of the digital services tax is turnover, no deduction of expenses is permitted, the overall profit/loss situation is irrelevant, it is not related to the profit margin and it is not creditable against corporate tax). ${ }^{1}$ The digital services tax is therefore allegedly compatible with tax treaties.

In their article 'Measuring and Interpreting Countries' Tax Attractiveness for Investments in Digital Business Models', Marcel Olbert, Christoph Spengel and Ann-
Catherin Werner analyse the attractiveness of locations for investments in digital business models. They find that investments in those models generally face lower average effective tax rates than those in traditional business models, even before considering special incentives. According to the authors, this outcome is related to the fact that a high share of investment costs is immediately expanded and a higher share of activities falls within the scope of countries' tax incentives for research and development input and or output. The authors acknowledge an increasing trend in tax competition for digital businesses, and recommend thoughtful policies targeting these businesses, taking into account their relevant impact on economic growth and productivity. ${ }^{2}$

Johannes Becker and Joachim Englisch ('Taxing Where Value is Created: What's "User Involvement" Got to Do With It?') critically discuss the argument that 'user contribution' is in general relevant to 'value creation' and may legitimately give rise to taxation rights. According to the authors, 'user contribution' is - in most cases - passive or limits itself to create externalities. They instead put forward the concept of sustained user relationships (SURE): (1) the network needs to be a stable relationship, (2) used by the firm for business purposes and (3) revealing a relevant size and depth of the user group. SURE would allegedly better align with the notion of 'value creation', than 'user involvement', and constitute intangible assets legitimizing taxation in the territory where SURE take place. ${ }^{3}$

Nadine Riedel and Patricia Hofmann were invited to comment on the article by Becker and Englisch. The authors still rely on current international tax principles, including the arm's length principle, and do not acknowledge SURE as a tax nexus connected to user relations, unless it were to be related to country-specific investments. Accordingly, in the absence of local country-specific investments, ownership of the user base asset is

\section{Notes}

D. Hohenwarter, G. Kofler, G. Mayr \& J. Sinnig, Qualification of the Digital Services Tax under Tax Treaties, in this issue, at 140.

M. Olbert, C. Spengel \& A-C Werner, 'Measuring and Interpreting Countries' Tax Attractiveness for Investments in Digital Business Models, in this issue, at 148.

J. Becker \& J. Englisch, Taxing Where Value is Created: What's 'User Involvement' Got to Do With It?, in this issue, at 161. 
plausibly with the country where the digital firm undertakes its core operations. ${ }^{4}$

Georg Kofler and Julia Sinnig, in 'Equalization Taxes and the EU's Digital Services Tax', address the general background and features of equalization taxes, the objections raised against them, and the characteristics of the digital services tax in the EU Proposal for a Directive. Legal uncertainty represents a major risk to the success of the digital services tax. Kofler and Sinnig call for further work on the distinction between covered and excluded services and the related vague concept of 'sole or main purpose'. Moreover, they suggest a profitability threshold to ensure the protection of smaller businesses and startups, or a combination of digital services tax in the sense of a minimum or default tax. ${ }^{5}$

Christina Dimitropoulou ('The Digital Service Tax and Fundamental Freedoms: Appraisal under the Doctrine of Measures Having Equivalent Effect to Quantitative Restrictions') assesses the European Commission Proposal for a Directive on a digital services tax in light of the EU free movement of goods and services. She finds that there is a high risk for the digital services tax to run counter to the aim of the digital single market, and holds that the digital services tax might be incompatible with the afore-mentioned fundamental freedoms. ${ }^{6}$ Dimitropoulou further proposes that digital intermediation services be excluded from the scope of the digital services tax until a comprehensive solution is reached. ${ }^{7}$

Aleksandra Bal, in her article titled 'Developing a Regulatory Framework for the Taxation of Virtual Currencies', develops a methodology for setting up an effective regulatory framework for the taxation of virtual currency transactions. She starts by reviewing virtual currency regulations in five countries and proposes a four-step methodology to develop the afore-mentioned regulatory framework, namely (1) data-driven assessment, (2) choice of the regulation method, (3) communication and (4) monitoring. ${ }^{8}$

The different views and perspectives published - except for the commentary by Hofmann and Riedel - take it for granted that the current system is evolving in order to accommodate the new digital economy, and will not resist including new tax nexus or new taxes. For example, whereas Olbert, Spengel and Werner conclude that tax competition targeting digital business is increasing and do not expressly propose coordination as the best policy, other authors propose either a new nexus (Becker and Englisch) or interim measures based on digital services taxes (Kofler and Sinnig), or criticize the latter as incompatible with the internal market (Dimitropoulou).

Compared to the research published in the June-July issue, these articles are more focused on specific problems or solutions, probably because the diagnosis of the current problems and the scenarios have already been clearly asserted in previous publications and in the OECD's Tax Challenges Arising from Digitalisation: Interim Report 2018.9

This issue also includes two book reviews. Anne van de Vijver reviews the 5 th edition of Tax Treaties by Jonathan Schwarz, ${ }^{10}$ while Marcos Lívio Gomes reviews The OECD Multilateral Instrument for Tax Treaties: Analysis and Effects, edited by Lang, Pistone, Rust, Schuch and Staringer. ${ }^{11}$

Enjoy your reading!

Ana Paula Dourado General Editor

\section{Notes}

4 N. Riedel \& P. Hofmann, Comment on J. Becker \& J. Englisch,'Taxing Where Value is Created: What's "User Involvement" Got to Do with It?', in this issue, at 172.

G. Kofler and J. Sinnig, in Equalization Taxes and the EU's Digital Services Tax, in this issue, at 176.

6 C. Dimitropoulou, The Digital Service Tax and fundamental freedoms: Appraisal under the doctrine of Measures Having Equivalent Effect to Quantitative Restrictions ('MEQR'), in this issue, at 201.

Dimitropoulou, supra n. 6, at 201.

8 A. Bal, Developing a Regulatory Framework for the Taxation of Virtual Currencies, in this issue, at 219.

9 OECD, Tax Challenges Arising from Digitalisation: Interim Report 2018 - Inclusive Framework on BEPS, OECD/G20 BEPS Project (OECD Publishing 16 Mar. 2018).

10 A. van de Vijver, Book review: J. Schwarz, Schwarz on Tax Treaties (5th edition, Kluwer Law International 2018), in this issue, at 234.

11 M. L. Gomes, Book review: M. Lang, P. Pistone, A. Rust, J. Schuch and C. Staringer eds., The OECD Multilateral Instrument for Tax Treaties: Analysis and Effects (Wolters Kluwer 2018) in this issue, at 239. 